\title{
A FEJLŐDÉSPSZICHOLÓGIA MAGYARORSZÁGON AZ ELMÚLT 30 ÉVBEN
}

\author{
KIRÁLY ILDIKÓ \\ MTA-ELTE Társas Elmék Kutatócsoport, ELTE Eötvös Loránd Tudományegyetem \\ Pszichológiai Intézet \\ E-mail: kiraly.ildiko@ppk.elte.hu \\ Benyújtva: 2021. március 25. - Elfogadva: 2021. május 6.
}

\begin{abstract}
A Magyarországon folyó fejlódéslélektani kutatások az elmúlt 30 évben jelentôs, nemzetközileg is elismert eredményekkel gazdagították ismereteinket. E tanulmány bemutatja a terület aktív kutatómühelyeit, és összefoglalja a kiemelkedô eredményeiket.
\end{abstract}

Kulcsszavak: fejlödéspszichológia, pszichológiatörténet, kiemelkedô eredmények 


\section{A FEJLŐDÉSKUTATÁS INTÉZMÉNYES KERETEI ÉS ENNEK KIBONTAKOZÁSA}

A Magyarországon végzett pszichológiai kutatások elmúlt 30 évének összefoglalásakor a fejlôdéskutatásnak kitüntetett szerep jut, hiszen ezt az idôszakot tulajdonképpen a terület megalapozásával és a hazai kutatómúhelyekben való elterjedésével jellemezhetjük. A 90-es évek elején az MTA Pszichológiai Kutatóintézetében alakul meg az a Fejlődéslélektani Osztály, melynek keretében két nagy hatású kutatócsoport dolgozik. Az egyik Gergely György vezetésével a társas megismerés fejlődésének vizsgálatával foglalkozik, a másik Gervai Judit irányítása mellett a szociális, érzelmi fejlődés, a kötôdés biológiai aspektusainak feltárására koncentrál. Mindkét csoport vezetố kutatója bekapcsolódik az egyetemi képzésbe, és részt vesz az Eötvös Loránd Tudományegyetemen a Kalmár Magda vezette fejlődéslélektani szakirányú oktatásba. A két kutatómúhely meghonosítja a laboratóriumi gyermekvizsgálatok hagyományát, és egyben ezen a területen a magas színvonalú kísérleti vizsgálatok alapvetố módszertani irányelveit, az ismeretek igazolásának e módszertanhoz kapcsolódó igényességét is átadja a pszichológusok új generációinak.

Az ezredforduló nemcsak hazánkban, de a világon mindenhol a fejlốdéskutatás reneszánszát hozta, mivel a kutatási infrastruktúra olyan mértékben fejlôdött, hogy lehetốséget nyitott arra, hogy egyre pontosabban és részletesebben tárhassák fel a kutatók a pszichológiai funkciók hátterében meghúzódó alapfolyamatokat, s így átfogóbb magyarázatot nyújtsanak az emberi természet sajátosságainak és az egyediségnek a kibontakozására. A terület iránt kinyíló érdeklődés mellett a kutatóhelyek és az egyetemek közötti kooperációnak is köszönhetô, hogy a 2000-es években több új, fejlôdési vizsgálatokra szakosodó kutatómúhely jön létre. Az akkori MTA Pszichológiai Kutatóintézetében éppen 2000-ben alakult meg az elsố fejlôdés-pszichofiziológiai kutatócsoport Csépe Valéria vezetésével, mely ma Honbolygó Ferenc irányításával az Eötvös Loránd Kutatási Hálózat Természettudományi Kutatóközponton (ELKH TTK) belül Neurokognitív Fejlődés Kutatócsoportként múködik. Ugyanígy az MTA Pszichológiai Intézetében indítja el a 2000-es évek elején Winkler István a hallási eseményszervezés feltárására irányuló, elektrofiziológiai módszerekkel zajló csecsemôvizsgálatait, melyek ma is zajlanak a Hang és Beszédészlelési Csoportban (szintén az ELKH TTK keretében). E két csoport kiemelkedô eredményeket ért el a kognitív fejlôdés-idegtudomány területén (munkájukról lásd bôvebben Csépe Valéria írását a jelen számban).

2008-ban Gergely György Csibra Gergellyel közösen megalapítja a Közép-európai Egyetem Fejlődéslélektani Kutatóközpontját (Csecsemốlaborját), ezzel egy idôben az ELTE Babalaborja is elindul Egyed Katalin és Király Ildikó közremúködésével.

Az elmúlt évtizedben újabb, csecsemôkre és kisgyermekekre fókuszáló kutatóhelyek kezdik meg múködésüket, többek között a Pázmány Péter Katolikus Egyetemen Hámori Eszter vezetésével, a Pécsi Tudományegyetemen Lábadi Beatrix irányításával, és az ELTE TTK Etológia Tanszékén az Alfa Generáció Labor Miklósi Ádám kezdeményezésére.

A fejlôdéskutatások elismertségét fémjelzi, hogy 2017-tôl a Közép-európai Egyetem Fejlôdéslélektani Kutatóközpontjának kezdeményezésére, az ELTE Babalaborjával történô összefogásban megszületik a Kis Tudósok Délutánja esemény, melyet évente rendeznek meg más-más intézmény szervezésében mint a hazánkban múködô 
fejlődéskutató laborok közös disszeminációs rendezvényét. Ma elmondható, hogy az elmúlt 30 év alatt Magyarország a fejlődéskutatás terén nagyhatalommá vált, s ez a Közép-európai Egyetem Fejlôdéslélektani Kutatóközpontjának - és annak a húzóerônek, referenciakeretnek, amelyet képvisel - nagyban köszönhetô.

\section{AZ ELMÚLT 30 ÉV KIEMELKEDŌ KUTATÁSI EREDMÉNYEI}

A hazai fejlôdéspszichológia a nemzetközi élvonalba emelkedett a területet vezetô, iránymutató kutatómúhelyek és kiemelkedô eredményeik révén.

Ez elsôsorban Gergely György és Csibra Gergely iskolateremtô munkáinak köszönhetô. Együtt gondolkodásuk gyümölcse két nagy hatású, újító elmélet, mely empirikus kutatások sokaságát inspirálta, és ma már tankönyvek alapeleme. A teleológiai hozzáállás elmélete úttörô szerepet vállal a fejlődéselméletek alapvetô kereteinek a formálásában, megújításában (Gergely, Nádasdy, Csibra és Bíró, 1995; Gergely és Csibra, 2003; Csibra és Gergely, 2007b), mely szerint az elsô életévben múködésbe lép az az értelmezési keret, mely révén mások - fajtársak, ágensek - viselkedését, cselekvését értelmezni tudjuk azok céljának és a környezeti feltételeknek a függvényében, mégpedig a racionális cselekvés elvének alkalmazásával, ami elôvételezi, hogy egy célhoz mindig a lehetô legegyszerúbb megoldást választják a cselekvôk. Az elmélet központi gondolata, hogy egy hozzáállás, egy modell az, ami egyszerú jelentések kikövetkeztetését, és így szervezett információ szelekcióját teszi lehetôvé. Ezzel a gondolattal példaértékú elméleti konstrukciót kínálnak arra, hogy a megismerô rendszer hogyan válik képessé következtetésekre, gyors alkalmazkodásra elóhuzalozott mechanizmusok segítségével.

Alkotómunkájuk idóben következô, innovatív eredménye a természetes pedagógia elmélete, mely elképzelés a fenti elméletformálás alapjaira épül (Gergely és Csibra, 2006; Csibra és Gergely, 2006; 2007a; 2009; 2011). A modell értelmében a humán kommunikáció arra szakosodott, hogy általános, új helyzetekre alkalmazható tudást közvetítsen az egyének között, különös tekintettel az újoncok, a kisgyermekek irányába. Minthogy az újoncok, a csecsemôk fogékonyak arra, hogy a kommunikáció feléjük irányul, és egy új tudásra vonatkozik, ez a szisztéma az elsôre nem könnyen belátható információk gyors és hatékony átadását segíti. A kulturális tudásátadás természetes pedagógiai modellje megold két jelentôs kihívást: a partner felől érkezô tanító szándék érzékelése felfüggeszti az egyéb értelmezési kereteket (például a korábban említett teleológiai hozzáállást), és a hallgató az információt oksági átláthatatlansága ellenére is mint releváns információt fogadja. Mi több, a tanító szándék jelenléte azt az elvárást is kiváltja benne, hogy az információ a relevanciáját abból nyeri, hogy a közös tudás részét képezi, azaz általánosítható tudáselem (Csibra és Gergely, 2006, 2011). Empirikus adatok támasztják alá, hogy a csecsemôk mások kommunikatív jelzéseit referenciális viselkedésként, azaz egy tárgyra vonatkozó jelekként kezelik (lásd még Topál, Gergely, Miklósi, Erdohegyi és Csibra, 2008); ezenkívül a csecsemók azt is feltételezik, hogy egy kommunikatív epizód mások számára is érvényes tudást közvetít (Egyed, Király és Gergely, 2013). A természetes pedagógia modellje erôs érvekkel szolgál arra vonatkozóan, hogy az emberi nem a társakra és a velük való kommunikációra támaszkodva kialakított egy hatékony tudásátadási értelmezési keretet. Sikeresen áthidalja azt, hogy 
az egyéni problémamegoldás számára átláthatatlan elemek hogyan válnak a tudás, mégpedig jellemzôen a közösen birtokolt tudás részévé.

A társas megismerés területén a tanítványok és az együttmúködő kollégák révén széles körben ismert és elismert, magasan hivatkozott kísérleti kutatási eredmények születtek. A teleológiai hozzáállás kiterjesztése az aktív cselekvés terén történô alkalmazásának igazolására és a társas tanulásra Gergely, Bekkering és Király (2002) munkája révén valósult meg. Topál és munkatársai (2008) rávilágítottak, hogy az A-nem-B hiba gyerekek általi elkövetésének hátterében húzódik meg az is, hogy a gyerekek elvárják, hogy a tanító másik fél egy általános érvényú tudást közvetítsen a kommunikáció során, s nem egy egyedi információt. Ez a munka nyitott lehetôséget kínált a komparatív kutatásoknak, hogy hasonló eszközökkel vizsgálják, hogyan értelmezik más fajok, így a kutyák és farkasok az emberi interakciókban megjelenô kommunikatív gesztusokat. A kutatások igazolták, hogy a gyerekekhez hasonlóan a kutyák - de farkasok nem új helyzetre általánosítják a társas helyzetben tanultakat (Topál, Gergely, Erdohegyi, Csibra és Miklósi, 2009).

A korai képességek feltárására tett erôfeszítések további kiemelést érdemlô eredménye Kovács, Endress és Téglás (2010) munkája, akik kimutatták, hogy már 7 hónapos csecsemôk, ahogyan felnôttek is, automatikusan képesek mások vélekedését olvasni. Eredményeik meglepetése, hogy a másokra érvényes vélekedések feldolgozását mind a csecsemók, mind pedig a felnốttek esetén a saját, elsố személyú cselekvés módosításán keresztül érték tetten. Ez a kutatási eredmény egy egészen új megvilágításba helyezte a társas megismerésen belül a tudatelmélet mibenlétét, mégpedig nemcsak arra hívta fel a figyelmet, hogy rendkívül korán elérhetô elemi képességrôl van szó, hanem arra is, hogy erôfeszítés nélkül múködik, és a saját viselkedés szervezésében is elsôdleges szerepet kaphat. A nagy hatású társas megismerési modellek nem csak az alapkutatásokat virágoztatták fel, de klinikai kutatások sorát inspirálták, és nyújtottak modellt a gyakorló szakembereknek (Fonagy, Gergely, Jurist és Target, 2002).

A társas megismerés területérôl továbblépve, további kutatások is áttörést hoztak a fejlődéskutatás terén, melyek egyenként hozzájárultak a hazai fejlôdéskutatás nemzetközi megismeréséhez. Lakatos és Gervai munkatársaikkal pszichogenetikai vizsgálatok segítségével (2000; 2002; Gervai és mtsai, 2007) alátámasztották, hogy a DRD4 gén változatai moderálják az anyai gondozás és a kötôdési viselkedés fejlôdésének ismert kapcsolatát kis és nagy szociális kockázatú populáció esetében egyaránt.

Kovács Ilona (2004) munkájának köszönhetôen alátámasztást nyert, hogy az észlelés és a vizuális integráció fejlődése lassú és összetett folyamat, mely a serdülôkorba nyúlik. Csépe Valéria és Honbolygó Ferenc kutatásaikkal hozzájárultak ahhoz az átfogó projekthez, mely feltárta, hogy az olvasási készségek hátterében milyen, a nyelvi sajátosságokat is tükrözô, kognitív folyamatok állnak (Moll és mtsai, 2014). A tanulás természetének vizsgálata kapcsán Janacsek, Fiser és Németh (2012) azt támasztották alá, hogy a tapasztalatokra és az azokban megjelenô ismétlődô szabályszerúségekre való érzékenység és erre alapozó tanulás tizenkét éves korig fejlődik, és ekkor a leghatékonyabb. Keresztes, Ngo, Lindenberger, Werkle-Bergner és Newcombe ugyanakkor a modelleken és szabályokon alapuló tanulást támogató emlékezeti rendszer fejlôdésének kutatását foglalják össze (2018), és érvelnek amellett, hogy a korai idôszakra jellemzô a generikus, általános tudás dominanciája, majd ezt váltja fel az egyedi, epizodikus tudásra való érzékenység. 


\section{KUTATÓK AZ ALKALMAZOTT TERÜLETEKÉRT}

A hazai fejlődéskutatás alapkutatásban végzett eredményei mellett ugyancsak kiemelkedô sikernek tekinthetô, hogy a kutatók a gyakorlatban dolgozó kollégákkal szoros együttmúködésben nagy ívú projektekre vállalkoztak, melyek célja a legfrissebb kutatási eredményekre támaszkodó gyakorlati munka megalapozása, azaz a kutatások eredményeinek alkalmazott területeken való, megújító alkalmazása.

Néhány kiemelkedô példát érdemes bemutatni. A Biztos Kezdet Program ${ }^{1}$ célja a nyitott párbeszéd megvalósítása a különbözô indíttatású szerzók, úgymint az akadémiai kutatók és a gyakorlati szakemberek között, annak érdekében, hogy kibontakozzon a gyakorlatban a korai fejlôdés optimális támogatása és ha szükséges, a hatékony intervenciós programok lehetôsége. E program kutatási tervét ketten fogták össze: Danis Ildikó fejlődéspszichológusnak nagy szerepe volt a mentorképzésben, mivel szerzôként, szerkesztôként is hozzájárult a program köteteinek összeállításához; a hatékonyságvizsgálatot pedig Surányi Éva közgazdász végezte.

Ennek a programnak a szellemiségét követi és gazdagítja a Semmelweis Egyetem Mentálhigiénés Intézete által 2020-ban kiadott, Danis Ildikó és munkatársai szerkesztésével elkészült A kora gyermekkori lelki egészség támogatásának elmélete és gyakorlata címú kötetpár, ${ }^{2}$ melyek hiánypótló módon tájékoztatják a területen dolgozó szakembereket a kutatásokon nyugvó szülô-csecsemô/kisgyermek pszichoterápia gyakorlatáról, és a nemzetközileg elismert és hazánkban elérhetô kapcsolat- és kötôdésalapú intervenciós programokról.

A másik példa az MTA támogatását élvezô, Győri Miklós és Stefanik Krisztina irányításával múködő MTA-ELTE Autizmus Szakmódszertani Kutatócsoport (MASZK) munkája és módszertani tájékoztató kiadványai. ${ }^{3}$ A kutatócsoport az autizmussal élő gyermekek és felnôtt szüleik életminôségérôl, pszichológiai jóllétérôl végzett kutatásokat, miközben kialakítottak egy, a vizsgált csoport befogadását elôsegítô egyedi intervenciós programot.

\section{IRODALOM}

Csibra, G., \& Gergely, Gy. (Eds) (2007a). Ember és kultúra: A kulturális tudás eredete és átadásának mechanizmusai. Budapest: Akadémiai.

Csibra, G., \& Gergely, G. (2006). Social learning and social cognition: The case for pedagogy. In Munakata, Y., \& Johnson, M. H. (Eds), Processes of Change in Brain and Cognitive Development. Attention and Performance XXI (pp. 249-274). Oxford: Oxford University Press.

Csibra, G., \& Gergely, G. (2009). Natural Pedagogy. Trends in Cognitive Sciences, 13(4), 148-153.

Csibra, G., \& Gergely, G. (2011). Natural pedagogy as evolutionary adaptation. Philosophical transactions of the Royal Society of London. Series B, Biological sciences, 12/366(1567), 1149-1157.

DOI: $10.1098 /$ rstb.2010.0319

\footnotetext{
$1 \quad$ https://mek.oszk.hu/14800/14803/14803.pdf; https://mek.oszk.hu/14800/14806/14806.pdf

2 https://semmelweis.hu/mental/files/2020/12/Kora-gyermekkori-lelki-egeszseg_I-kotet.pdf; https:/ / semmelweis.hu/mental/files/2020/12/Kora-gyermekkori-lelki-egeszseg_II-kotet.pdf; https://semmelweis. hu /mental/2020/12/14/megjelent/

https://maszk.elte.hu/tajekoztatok/MASZK\%20kutatas_tajekoztato\%20kiadvany.pdf; https://csiip. elte.hu/CsIIProgram/CsIIP_tajekoztato\%20kiadvany.pdf
} 
Csibra, G., \& Gergely, G. (2007b). 'Obsessed with goals'. Fuctions and mechanism of teleological interpretation of actions in humans. Acta Psychologica, 124, 60-78.

Egyed, K., Király, I., \& Gergely, Gy. (2013). Communicating Shared Knowledge in Infancy. Psychological Science, 24(7), 1348-1353. DOI: 10.1177/0956797612471952

Fonagy, P., Gergely, G., Jurist, E. L., \& Target, M. (2002). Affect regulation, mentalization, and the development of the self. Other Press.

Gergely, G., Nádasdy, Z., Csibra, G., \& Bíró, S. (1995). Taking the intentional stance at 12 months of age. Cognition, 56(2), 165-193. DOI: 10.1016/0010-0277(95)00661-h

Gergely, G., \& Csibra, G. (2003). Teleological reasoning in infancy: The naive theory of rational action. Trends in Cognitive Sciences, 7, 287-292.

Gergely, G., \& Csibra, G. (2006). Sylvia's recipe: The role of imitation and pedagogy in the transmission of human culture. In Enfield, N. J., \& Levinson, S. C. (Eds), Roots of Human Sociality: Culture, Cognition, and Human Interaction (pp. 229-255). Oxford: Berg Publishers.

Gergely, G., Bekkering, H., \& Király, I. (2002). Rational imitation in preverbal infants. Nature, 415,755 .

Gervai, J., Novak, A., Lakatos, K., Toth, I., Danis I., Ronai, Z., et al. (2007). Infant genotype may moderate sensitivity to maternal affective communications: attachment disorganization, quality of care, and the DRD4 polymorphism. Social Neuroscience, 2, 307-319.

Janacsek, K., Fiser, J., \& Németh, D. (2012). The best time to acquire new skills: age-related differences in implicit sequence learning across the human lifespan. Developmental Science, 15(4), 496-505.

Keresztes, A., Ngo, Ch. T., Lindenberger, U., Werkle-Bergner, M., \& Newcombe, N. S. (2018). Hippocampal Maturation Drives Memory from Generalization to Specificity. Trends in Cognitive Sciences, 22(8), 676-686.

Kovács, Á., Téglás, E., \& Endress, A. D. (2010). The Social Sense: Susceptibility to Others' Beliefs in Human Infants and Adults. Science, 330(6012), 1830-1834.

Kovács, I. (2004). Visual Integration: Development and Impairments. Budapest: Akadémiai.

Moll, K., Ramus, F., Bartling, J., Bruder, J., Kunze, S., \& Neuhoff, N., et al. (2014). Cognitive mechanisms underlying reading and spelling development in five European orthographies. Learning and Instruction, 29, 65-77. https://doi.org/10.1016/j.learninstruc.2013.09.003

Lakatos, K., Nemoda, Z., Toth, I., Ronai, Z., Ney, K., Sasvari-Szekely, M., \& Gervai, J. (2002). Further evidence for the role of the dopamine D4 receptor (DRD4) gene in attachment disorganization: interaction of the exon III 48-bp repeat and the $-521 \mathrm{C} / \mathrm{T}$ promoter polymorphisms. Molecular Psychiatry, 7(1), 27-31. DOI: 10.1038/sj.mp.4000986

Lakatos, K., Toth, I., Nemoda, Z., Ney, K., Sasvari-Szekely, M., \& Gervai, J. (2000). Dopamine $\mathrm{D} 4$ receptor (DRD4) gene polymorphism is associated with attachment disorganization in infants. Molecular Psychiatry, 5(6), 633-637. DOI: 10.1038/sj.mp.4000773

Topál, J., Gergely, G., Miklósi, A., Erdohegyi, A., \& Csibra, G. (2008). Infants' perseverative search errors are induced by pragmatic misinterpretation. Science, 321(5897), 1831-1834. DOI: $10.1126 /$ science.1161437

Topál, J., Gergely, G., Erdohegyi, A., Csibra, G., \& Miklósi, A. (2009). Differential Sensitivity to Human Communication in Dogs, Wolves, and Human Infants. Science, 325(5945), 1269-1272. DOI: 10.1126/science. 1176960 


\title{
DEVELOPMENTAL PSYCHOLOGY IN HUNGARY FOR THE LAST 30 YEARS
}

\begin{abstract}
KIRÁLY, ILDIKÓ
Research in the field of developmental psychology in Hungary has contributed to scientific advancement with significant, internationally recognized findings over the past 30 years. This paper introduces the active research groups in the field and summarizes their outstanding findings.
\end{abstract}

Keywords: developmental psychology, history of psychology, outstanding research findings

A cikk a Creative Commons Attribution 4.0 International License (ttps://creativecommons. org/licenses/by/4.0/) feltételei szerint publikált Open Access közlemény, melynek szellemében a cikk bármilyen médiumban szabadon felhasználható, megosztható és újraközölhetô, feltéve, hogy az eredeti szerzô és a közlés helye, illetve a CC License linkje és az esetlegesen végrehajtott módosítások feltüntetésre kerülnek. (SID_1) 